\title{
Mapping the field of family business research: past trends and future directions
}

\author{
Jing (Melanie) Xi • Sascha Kraus • Matthias Filser • \\ Franz W. Kellermanns
}

Published online: 10 December 2013

(C) Springer Science+Business Media New York 2013

\begin{abstract}
Receiving increasing attention over the past decade by scholars worldwide, family business research has developed in diverse directions. Due to the numerous challenges family businesses face in their development and continuation, research has generated a wide ranging spectrum of the subjects explored within it and a large body of knowledge as a result. Based on the results of the by far largest bibliometric analyses in the field, this paper elaborates and clarifies the fragmented state of family business research. By analyzing virtually all existing family business-related writings, the most
\end{abstract}

Funding for this project was provided by: "A Multilevel Dynamic Study on Successor Identity Construction among Family business' Next Generation and Its Effects on Their Intention and Behavior Regarding Succession", National Natural Science Grant by National Natural Science Foundation of China, granted in 2013 (Project No. 71302137).

\section{J. M. Xi}

School of Management, Research Center of Enterprise Management Innovation, Guangdong University of Technology, Guangzhou, China

e-mail: melaniexi@163.com

S. Kraus $(\bowtie) \cdot$ M. Filser

Institute of Entrepreneurship, University of Liechtenstein, Fürst-Franz-Josef-Strasse, 9490 Vaduz, Liechtenstein

e-mail: sascha.kraus@uni.li

M. Filser

e-mail: matthias.filser@uni.li

S. Kraus

Swiss Research Institute of Small Business and Entrepreneurship, University of St. Gallen,

Dufourstrasse 40a, 9000 St. Gallen, Switzerland

F. W. Kellermanns

Belk College of Business, UNC Charlotte, 206B Friday, 9201 University City Blvd, Charlotte,

NC 28223-0001, USA

e-mail: kellermanns@uncc.edu

F. W. Kellermanns

INTES Center for Family Enterprises, WHU (Otto Beisheim School of Management),

Vallendar, Germany 
influential publications are highlighted, and changes in citation patterns before and after the year 2000 are discussed. Here, five topical clusters are identified which reflect the tracks family business research follows. With these clusters as a basis, the paper concludes by identifying avenues for future research.

Keywords Family business research · Bibliometrics · Citation analysis · Content analysis

\section{Introduction}

Dominating economies worldwide and offering a distinctive research domain (Aldrich and Cliff 2003; Gedajlovic et al. 2012), family businesses have generated and attracted a great deal of research interest during the past few decades (e.g., Wright and Kellermanns 2011; Sharma et al. 2012), resulting in higher-quality publications (Gedajlovic et al. 2012).

With the 25th anniversary of Family Business Review (Sharma et al. 2012) in 2012 and the maturing of the field of family business, many publications are reviewing, summarizing, and rethinking developing trends and future tasks of this field from different perspectives (Debicki et al. 2009; Chrisman et al. 2010; Kraus et al. 2011b; Wright and Kellermanns 2011; Gedajlovic et al. 2012; Sharma et al. 2012). Our study specifically builds on two of these papers (while at the same time going beyond them in terms of width and methodology): Chrisman et al. (2010) and Debicki et al. (2009).

Chrisman et al. (2010) identify 25 particularly influential articles and discuss their most important contributions to scholars' current understanding of family business. This analysis was based on articles published between 2002 and 2007 in the four most popular family business journals. We expand on their research by opening the citation analysis up to all journal articles published on family business until 2012 (1,103 total). Furthermore, we consider any type of reference in the results, which was limited to journal articles by Chrisman et al. (2010).

Debicki et al. (2009) focus on the contributions of individual scholars and academic institutions and the interrelationships between them by analyzing 291 family business articles published in 30 management journals between 2001 and 2007. Here again, we expand on this research. By including virtually all family business articles ever published, we can conduct a more finely-tuned analysis of these interrelationships and provide a forum for those working in non-management areas (e.g., finance, accounting) who were previously omitted from analysis. Recent years have seen the interest in family business in non-management areas also grow exponentially.

Our study makes multiple contributions to the literature. It provides the first truly comprehensive overview of family business research across business disciplines. Previous reviews have not included books in their results, even though some of these works have made a tremendous impact on the field (e.g., Rosenblatt et al. 1985; Ward 1987; Gersick et al. 1997). Their inclusion allows us to provide a more comprehensive review. Second, it sketches the scope and distinction of the field by identifying topic clusters, indicating a fragmented research focus in the family business field. Third, it presents the evolution path of each cluster to achieve a better understanding about the history of the field and the direction for future research as a result. Last, family business research needs to develop and build on established scientific 
achievement (Kuhn 1962). Frequently cited articles may indicate the field's core assumptions and insights.

\section{Family business research as a field of interest}

Although family businesses have enjoyed what can be considered a worldwide dominance for many years (for an overview, see La Porta et al. 1999), family business research was slow to gain traction and accumulate a body of knowledge (Sharma 2004; Gedajlovic et al. 2012). The number of family business publications has been increasing exponentially since 2000 , with an even greater acceleration in recent years. While it is probably impossible to identify all the catalysts of this development, the creation of family business conferences (e.g., ifera, FERC) and the special issues and topics found in academic journals and at conferences may very well have further legitimized the field (Wright and Kellermanns 2011).

In addition to these arguments, heightened interest may result from the recognition that family businesses are distinct organizational forms. Because they must cope with the unique interaction between family and business (Chrisman et al. 2010), this dyad offers an appealing context for studying organizational phenomena (Lansberg and Astrachan 1994).

Considering that the majority of businesses are family businesses, omitting family business-relevant controls at the very least leads to an incomplete and under-identified knowledge base (Dyer 2003). As Gedajlovic et al. (2012) note: "studying family firms can contribute important new insights to many of the issues and questions with which mainstream management scholars are currently grappling" (p. 2). A prime example is the theoretical development of agency theory, which has been significantly enriched by insights from family business (e.g., Schulze et al. 2001) and, incidentally, is one of the core literature bases in the family business literature.

\section{Methodology}

We use bibliometric citation analysis to investigate the development and evolution of family business research over the last few decades as well as its current state. We conduct an overall (i.e. across all years) as well as a decade-based citation analysis, followed by a discussion of the most frequently cited articles. By analyzing the most frequently cited and most influential publications and their focal points as a result, we can better understand this field's main research streams.

\section{Bibliometric analysis}

The use of bibliometric citation analysis allows us to elaborate not only on the intellectual structure of the field of family business research, but the development of scientific fields as well (Prévot et al. 2010). Citation analyses, which are essential to bibliometrics, examine the correlation between who and what is cited and the publication that contains the citations. The frequency of citations indicates their importance and qualitative value (Moed 2005). Therefore, a regularly cited publication conveys 
important scientific findings and constitutes a substantial foundation for further elaboration, representing a central contribution to the respective research discipline (Yue and Wilson 2004). While initial bibliometrics have been conducted in the field of family business research, they have only focused on selected journals and are limited in their analysis (Casillas and Acedo 2007; Chrisman et al. 2010; Benavides-Velasco et al. 2013). Accordingly, we significantly expand upon prior analysis by extending the citation pool to include virtually all family business papers published before 2012 .

\section{Research design}

Various methods facilitate the development and creation of clusters within citation research. The method applied here is well established and has often been used in similar studies (Casillas and Acedo 2007; Prévot et al. 2010; Kraus et al. 2011a; Kraus et al. 2013).

As a first step, in March 2012 we identified key documents. The original dataset was determined by publications published before 2012 containing the terms "famil*" (family, families, familial) and "business*" (business, businesses), "control*" (control, controlled), "enterprise*" (enterprise, enterprises), "firm*" (firm, firms), or "own*" (owned, owner, ownership), in their titles. We browsed databases such as ABI Inform/ ProQuest, EBSCO, Emerald, Google Scholar, ingentaconnect, JSTOR, MENDELEY, ScienceDirect, Scopus, and Springer. These databases represent major academic search engines in social science and were selected to facilitate a wide-ranging identification of publications that correspond to the search criteria. Each identified article was again checked manually to see whether it focuses on family business research or not. Furthermore, all articles published before 2012 in the Family Business Review, the Journal of Family Business Strategy, and the Journal of Family Business Management were included in our dataset, resulting in a total of 1,103 publications and 47,295 citations that fulfill these criteria. The author names, publication year, publication title, output channel/journal and reference type of each publication selected for the analysis as well as the cited references were then manually transcribed into an Excel sheet. The manual data input enabled the dataset to be checked in terms of consistency and allowed an identification and correction of any existing citation errors. In addition, the procedure was a necessary step in creating an electronic database which could then be analyzed using network analysis software.

The analysis then determined the 25 most frequently cited publications and/or authors, the amount of citations, and the most frequently cited journals. The focus on the top 25 most frequently cited publications helps achieve the objective of clarity, compactness, and overall practicality (for similar approaches, see e.g. Gundolf and Filser 2013; Prévot et al. 2010). After this, we identified topic clusters based upon content similarities. The identification of the clusters and the assignment of each article to a cluster were performed based on the authors' subjective evaluation. In doing this, each author individually examined the most frequently cited articles in terms of study subject, research question and findings, and created topic clusters while assigning each article to one of the identified clusters. The results of all authors were then compared. In the cases where assignments showed inconsistencies, the disparities were discussed among all authors to arrive at a consensual decision. The contents in each cluster were then discussed and reflected upon. 
We also provide a subset analysis in which the data is split into articles published before and after 2000 to allow a discussion of the changes and developments occurring in this field over time. The separation into an early (1964-1999) and a late period (2000-2011) was done because before 2000 the number of publications was stagnating, with most of them being published in the Family Business Review. Furthermore, solely 15 articles were published before the launch of the Family Business Review in 1988, which makes an analysis of articles written prior to 1988 anything but appropriate. After 2000 the number of publications rose constantly and output channels other than Family Business Review gained in importance. The growth in the number of publications after 2000 in particular was accompanied by the investigation of more specific subject areas. So separating the dataset into articles published before and after 2000 will be invaluable as we uncover the development of the field.

\section{Results}

As shown in Fig. 1, the overwhelming majority of published materials are journal articles, although a substantial number of books have also been published. This may indicate the immaturity of the field, as it is difficult to place family business articles in top-tier academic journals. It may also indicate the relevance for and demand of practitioners who typically prefer books. And, the lower number of citations in working papers and proceedings is not surprising, given that these outlets are less cited in general, and considering that only a small (but growing) number of papers are presented at major conferences (e.g., Wright and Kellermanns 2011).

Figure 2 provides an overview of the most frequently cited journals. Family Business Review and Entrepreneurship Theory and Practice, where the majority of papers are published, received the highest amount of citations. Papers published in toptier journals (Academy of Management Journal, Strategic Management Journal, Administrative Science Quarterly) are cited disproportionately.

Figure 3 shows the overview of the citation clusters for all identified studies. The authors in the center of the network matrix represent the most frequently cited references; the authors surrounding these references reflect the publications that were used as a basis for the bibliometric analysis. For reasons of space, and to enhance the figure's clarity, not all analyzed publications $(1,103)$ are shown. Only articles that cited at least six of the 25 most frequently cited publications are illustrated in the outer circle. The number in the

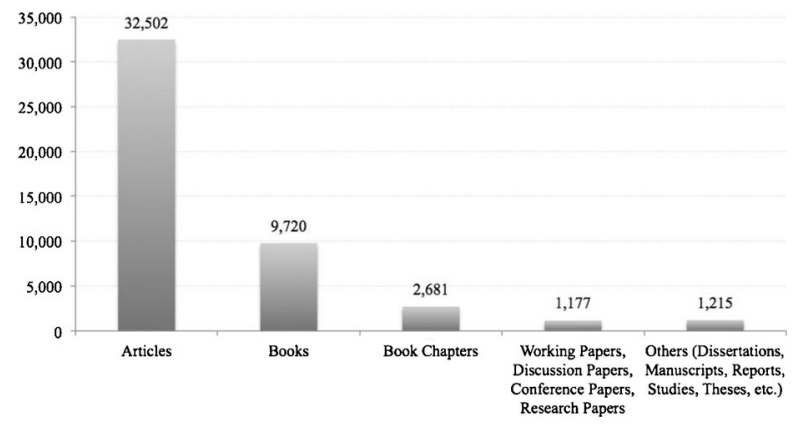

Fig. 1 Nature of cited literature 


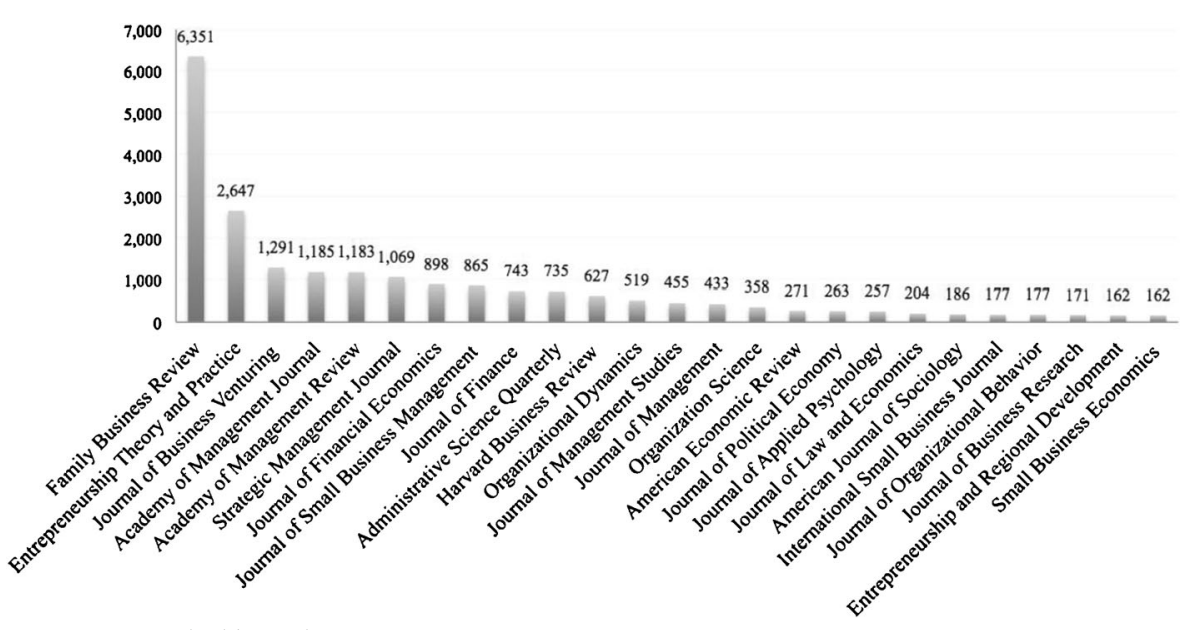

Fig. 2 Top 25 cited journals

upper right corner of each author/pair of authors in the center of the network matrix indicates the number of citations. The analysis yields five clusters of the 25 most frequently cited papers. We will discuss these clusters (numbered 1 to 5) in turn below.

\section{Top 25 publications}

We analyze the publications in each cluster regarding their key points and contributions to the literature; some have more than one focus. For example, studies of corporate governance may also look at competence, management, or succession, while leadership studies may examine governance or next generation. These publications are not meant to be separated into different clusters. Instead, their views of the topics of family business research clusters may overlap.

\section{Cluster 1: defining pieces}

Kets de Vries (1993) reveals the special dynamics of family businesses that contribute to their failure. Based on consultation work and in-depth interviews with over 300 family business executives, the author outlines the advantages and disadvantages of family businesses. Advantages include family culture, greater resilience in times of crisis, and greater flexibility in decision making. In addition, the author provides suggestions designed to prevent the company from becoming a casualty of family drama, an area that warrants further research attention.

Shanker and Astrachan's (1996) work is a foundational piece that defines family businesses. The authors developed criteria regarding family involvement that classifies family businesses based on broad, middle, and narrow definitions. They further show the impact of family businesses on the U.S. economy, which has promoted the importance of family businesses in both academic and non-academic settings.

Chua et al. (1999) build on earlier work and develop a definition of family business which has become the dominant definition and operationalization in the literature. They see behavior as the essence of a family business, with its differences distinguishing 


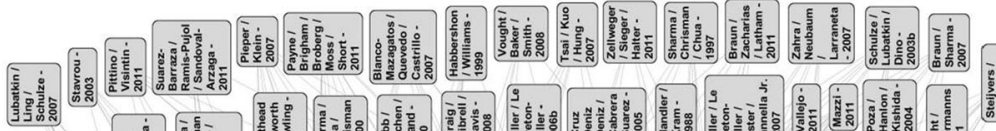

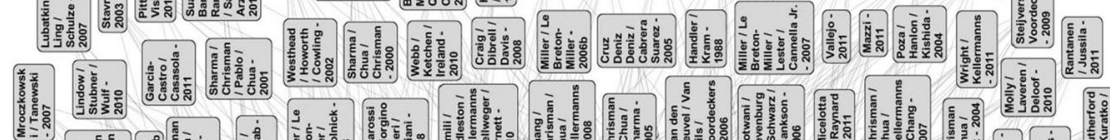

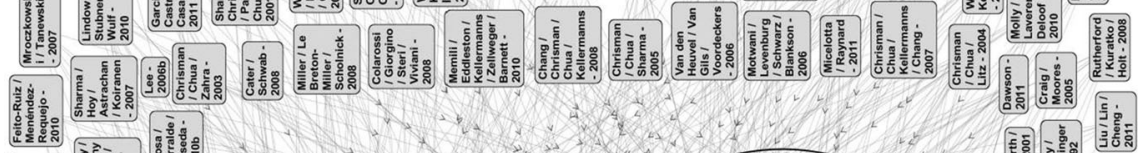

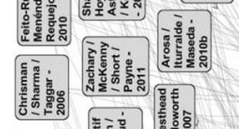

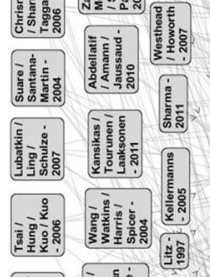
iiii in: in: in

iith iliw li: Hin illin II Iimis ail ii

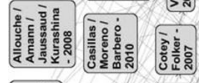
With Williti: Wilt inili ili Wits inl in Iit ilitis

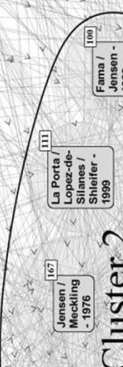

ili
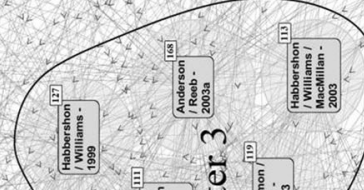

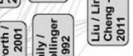
[3. If II iin ilis Iit in in

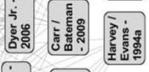
is $\operatorname{lin}$ hill If iin in If il in in ile ili li) $\operatorname{lin}$ ititi [ing [if $\operatorname{lin}$ (is [II:

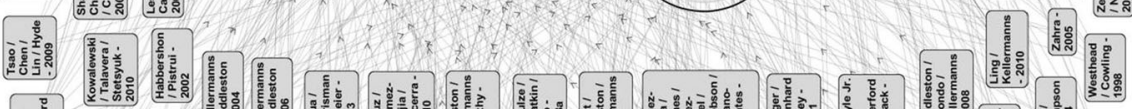

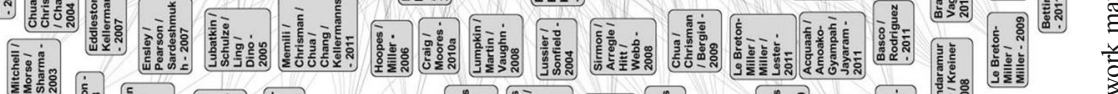

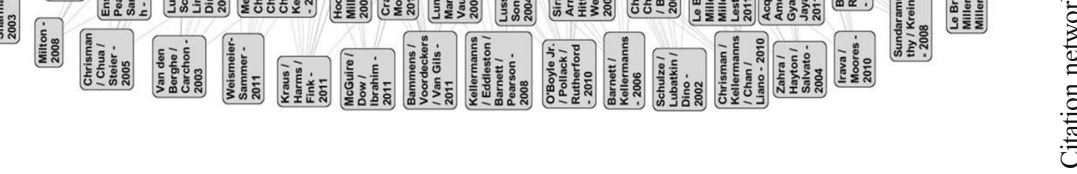


family and non-family businesses. They specifically define family businesses as "... governed and/or managed with the intention to shape and pursue the vision of the business held by a dominant coalition controlled by members of the same family or a small number of families in a manner that is potentially sustainable across generations of the family or families" (p. 25).

Sharma (2004) also discusses definitional issues of family businesses, developing a $2 \times 2$ matrix that facilitates the understanding of family business performance along business and family harmony dimensions. Her paper, a key foundational piece that stresses the pursuit of a combination of financial and non-financial goals, can be seen as an early predecessor of socio-emotional wealth (SEW) (Gómez-Mejía et al. 2007), which is currently developing into a dominant perspective in the family business literature. In addition, the paper outlines many avenues for future research that still need to be fully pursued.

Chrisman et al. (2005) discuss the underlying philosophy of the component and the essence approaches of family business. The component approach is based on the belief that family involvement is sufficient for a family to exist. The essence approach, however, suggests that although family involvement is a necessary condition, it must result in certain distinctive behaviors before the firm can be considered a family business. They further suggest that the resource based view (RBV) and agency theory are fruitful avenues for future research, particularly in exploring the effects of noneconomic goals in family businesses.

In summary, the debate regarding whether family business is a worthwhile research pursuit has been answered with a clear yes (Chrisman et al. 2010; Gedajlovic et al. 2012). The papers in this cluster have had and will have a profound influence on future research in the field while they at the same time continue to influence work in the other clusters.

\section{Cluster 2: governance in family businesses}

This is the largest of the identified clusters. Corporate governance is defined as the structure of rights and responsibilities among the parties with a stake in the firm (Aguilera and Jackson 2003). In family business research, governance topics focus on how family involvement affects the structure and role of the governance system.

Jensen and Meckling's (1976) seminal article identifies the most effective governance structure by utilizing agency theory. In the relationship between principal (the party who delegates work to others) and agent (the party who performs the work), agency cost occurs when the two parties have different goals and divisions of labor. Agency costs are defined as the sum of the monitoring expenditures by the principal, the bonding expenditures by the agent, and the residual loss owing to divergent interests and contracting imperfections. The authors point out that family owners have stronger incentives than minority shareholders to monitor managers because the former, when typically holding undiversified portfolios and investing primarily in their own companies, bear the entire cost of monitoring. Moreover, families with private knowledge of their own family dynamics may monitor their managers more effectively. As discussed in greater detail (e.g., Chrisman et al. 2010), this piece has triggered a more finely-tuned development of agency theory for family businesses that has informed not only family business literature, but wider governance research as well. 
In a second seminal agency paper, Fama and Jensen (1983) argue that, although the separation of ownership and management control can lead to agency problems, the efficiencies gained from separating residual claimants from decision makers exceed the costs in large organizations. They concentrate on the role of the board of directors that shareholders could use as a control mechanism to mitigate moral hazard problems among top executives.

Comparing family owned and managed firms with professionally managed firms, Daily and Dollinger (1992) investigate performance consequences when ownership and control of the firm are aligned. A field survey indicates that significant differences across structural, process, and performance dimensions exist, and there is evidence that firms that are family owned and managed exhibit performance advantages as a result of the unification of ownership and control. The authors also suggest that family businesses are more likely to use informal control systems than non-family businesses, which usually leads to outperformance of owner controlled family businesses compared to management controlled, non-family businesses.

Schulze et al. (2001) can be credited with bringing family business research to the forefront with the appearance of their article in a premier journal. They note that even privately held, owner managed firms may face agency threats in the form of owners' opportunistic behavior, which is overlooked by Jensen and Meckling's (1976) agency model. Schulze et al. (2001) argue that family dynamics (altruism in particular) exacerbate the agency problems experienced by privately held, owner managed firms. However, later research has shown that while agency costs exist in family businesses, they tend to be lower than in non-family businesses (Chrisman et al. 2004).

La Porta et al. (1999) emphasize the relatively greater importance of owner-owner agency problems, i.e. agent conflicts between controlling and minority shareholders. Furthermore, they provide a detailed picture of the ownership structure of large publicly traded companies around the world, suggesting that the theory of corporate governance focuses more attention on controlling shareholders who expropriate benefits from minority shareholders.

Gómez-Mejía et al.'s (2001) work broadens the scope of agency problems to emotional contracts rooted in family relations. Drawing from all Spanish newspapers over a 27-year period, they compare the influence of family and non-family contracting on monitoring mechanisms. Results indicate that monitoring mechanisms operate differently under family and non-family principal agent contracts and under stronger and weaker relational contracts. They suggest that family ties can increase agency costs as a result of executive entrenchment. Similar to Schulze et al. (2001) and Schulze et al. (2003), they show that the family can introduce as well as mitigate agency costs (Jensen and Meckling 1976).

Based on interviews with members of 59 family businesses, Rosenblatt et al. (1985) provide an overview of issues faced by family businesses. Starting with a psychological angle, they highlight potential frictions and therefore potentially evolving conflicts in the family and business environment. The authors emphasize the difficulty in keeping issues that concern the family or the business in the respective sphere, which has become a widely adopted stance by researchers and practitioners alike. Issues such as the involvement and compensation of family members, difficulties in decision making, leadership, and legacy, as well as aspects such as authority, prosperity, and status are addressed.

In the last study in this cluster, Lansberg (1983) describes conflicts in human management decision making caused by contradictions between the norms and 
principles that dominate the family and those that dominate the business. The article provides early guidance for selection, compensation, appraisal, training, and development, while offering suggestions for managing problems caused by the separation of management and ownership.

In summary, the governance cluster, the largest identified in this study, has probably had the greatest impact on the field and has also "given back" the most to the mainstream, non-family business literature.

\section{Cluster 3: competitive advantage}

The five articles in this cluster focus on issues that have a major impact on business performance. Linked through the RBV, the papers suggest that family business-specific resources and capabilities can lead to competitive advantages and disadvantages vis-àvis non-family businesses.

Sharma et al. (1997) point out that prior literature mainly focuses on family relationships rather than on how these relationships affect family business performance. Therefore, they make an appeal to researchers to focus more attention on outcomes, whether family harmony, economic performance, or other goal achievements, to improve management practice and organizational performance. Another important theoretic contribution of this work is how it provides an umbrella framework for future family business research and identifies a number of family business performance facets. The focus on family business outcomes has recently culminated in a review that analyzes all family business-related outcomes (Yu et al. 2012).

Habbershon and Williams (1999) introduce the term "familiness" to the literature. Using the RBV as a theoretical foundation, they define familiness as "the unique bundle of resources a particular firm has because of the systems interaction between the family, its individual members, and the business" (p. 11) and argue that the unique behavioral social phenomena within family businesses can be transferred into competitive advantages. Building on this study, Habbershon et al. (2003), who are also ranked in the top 25 , develop a unified systems model of family business performance. They assert that distinctive familiness can lead to family-based advantages by which enterprising families create trans-generational wealth.

Sirmon and Hitt (2003) develop a resource management process model based on the RBV that can lead to a competitive advantage in family businesses. Their model consists of three components: resource inventory (evaluating, adding, and shedding), resource bundling, and resource leveraging. They explain the challenges and opportunities family businesses encounter in managing resources and identify five types of resources that family businesses are more likely to possess than non-family businesses: human capital, social capital, patient financial capital, survivability capital, and governance structures.

Drawing from a sample of 403 S\&P 500 companies, Anderson and Reeb (2003) provide the first strong empirical evidence that family businesses perform better than non-family businesses. Their results imply that family ownership is an effective organizational structure in well-regulated and transparent markets because family ownership of public firms reduces agency problems without leading to severe losses in decision making efficiency. Their study has sparked a strong debate in the family business literature and generated additional work that qualifies its results (e.g., Miller 
et al. 2011; Van Essen et al. 2011). However, considering that family businesses often pursue non-economic goals that may not be entirely consistent with the pursuit of economic performance, studies in this realm (at least so far) paint only a partial picture.

In summary, this cluster helps us to better understand the competitive advantage of family business. While the concept of familiness is extremely popular and has prompted theoretical extensions (Zellweger et al. 2010), operationalization of this construct has proven highly contentious in empirical research and poses a challenge for the future.

\section{Cluster 4: leadership and management}

The cluster of leadership and management is composed of two books and two articles that provide rich data and vivid anecdotes regarding problems and opportunities many family businesses confront. It should be noted that the books in this cluster are among the only three publications (in addition to Daily and Dollinger 1992) that are ranked in the general top 25, the top 25 before 2000, and the top 25 after 2000.

Villalonga and Amit (2006) show that family ownership creates value only when the founder serves as CEO of the firm or as chairman (with a hired CEO). They suggest that minority shareholders can be exposed to two agency problems that affect firm value: a conflict of interest either with firm managers, or a conflict with other large controlling shareholders. In the context of family businesses, the crucial issue is whether the CEO is the founder or a descendant; if the latter, then firm value is mitigated. Identifying the role of founder as an important context variable further strengthens the nomological network of corporate governance.

Levinson (1971) stresses the negative consequences of conflicts created by rivalries among family members in family businesses and offers advice on how relatives can cope with such situations. Although conflict is a core area of concern, we know surprisingly little about it and even less about conflict management in family businesses (for exceptions, see Sorenson 1999; Kellermanns and Eddleston 2004; Kellermanns and Eddleston 2007). The article's solution is to move toward professional management. While this advice has often been given to family businesses and is reflected in the literature (Stewart and Hitt 2012), it should be noted that there is no reason to assume that family business members cannot be professional managers.

Based on research and interviews with leaders of family businesses, Ward (1987) encourages family business leaders to develop a plan to sustain the business across generations. He suggests that such planning should reconcile the needs of the business with the needs of the family. As he stresses that family businesses can have advantages unique to the family aspect, his work is the intellectual predecessor of the familiness concept (Habbershon et al. 2003). The many practical issues it discusses make it a popular book for both consultants and family business members.

Using extensive data drawn from more than 40 family businesses, Dyer (1986) stresses the importance of culture. He specifically identifies three topical areas regarding family business culture: (1) cultural patterns of typical family businesses as they change across time; (2) key problems that may occur during three stages of development; and (3) managing the change process. The book thus presents a rational, logical, and evolutionary approach for practitioners to follow when managing change.

In summary, Cluster 4 stresses the importance of good management and leadership in family businesses. Surprisingly little is known about these areas of research, and 
actual applications of leadership theories to the realm of family management are virtually non-existent.

\section{Cluster 5: succession}

The cluster of succession is the smallest one, composed of two articles and a book. In spite of its size, the study of succession has captured the attention of family business scholars since the field's inception (for a recent review, see De Massis et al. 2008). Work in this area draws strongly from the tenets of general systems theory, indicating its underlying complexity.

Lansberg (1988) focuses on factors interfering with succession planning in first generation family businesses, stressing that lack of succession planning is one of the most important reasons why many family businesses do not survive beyond the first generation. After noting that the main obstacle to succession planning is that the founder, the family, the owners, the senior managers, and other stakeholders typically experience ambivalent feelings toward succession planning, he then provides suggestions for overcoming this resistance. His paper is still highly relevant, as recent research finds succession planning to be most beneficial in first-generation firms (Eddleston et al. 2013).

Beckhard and Dyer (1983) suggest that succession is typically a problematic issue, since only $30 \%$ of family businesses survive the transition to a second generation and only $10 \%$ transition to the third generation. They assume an average firm life span of 24 years, the same as the average life tenure of the founder. By highlighting the difficult transition from founder to second generation leader, the authors identify the complex systematic structure of family businesses and examine critical variables that need to be addressed during the transition process.

Gersick et al. (1997) suggest that family businesses tend to progress through a sequence of stages, adding a developmental dimension to the idea of overlapping systems in family businesses. They also suggest that a family business adopts a particular characteristic in each life stage (controlling owner, sibling partnership, cousin consortium), taking on new characteristics as it advances to a new stage. Their insights have been tremendously influential and have provided structure in other influential publications (e.g., Schulze et al. 2003).

\section{Post-hoc analysis}

We have discussed the top 25 publications in terms of total citations. To help spot recent trends, we also split the analysis into two sub-sets: publications published before 2000 and publications published after 2000 (see Table 1). The most influential publications in the dataset before 2000 are references published between 1964 and 1993. With only four published in the 1990s, they represent the early stage of the field's development. Three publications overlap with the list after 2000, and ten appear in the general top 25 list. Most of these early publications have been criticized for being descriptive rather than prescriptive. Even though only two are empirical, focusing mainly on succession and legitimation, they build the true foundation of the field and have the potential to lead to new and innovative research.

The top 25 publications cited after 2000 appeared between 1976 and 2006, with only four published before 1990 (see Table 1). This list overlaps with the general top 25 list on 19 publications; only 6 are unique (Litz 1995; Davis et al. 1997; Westhead and 


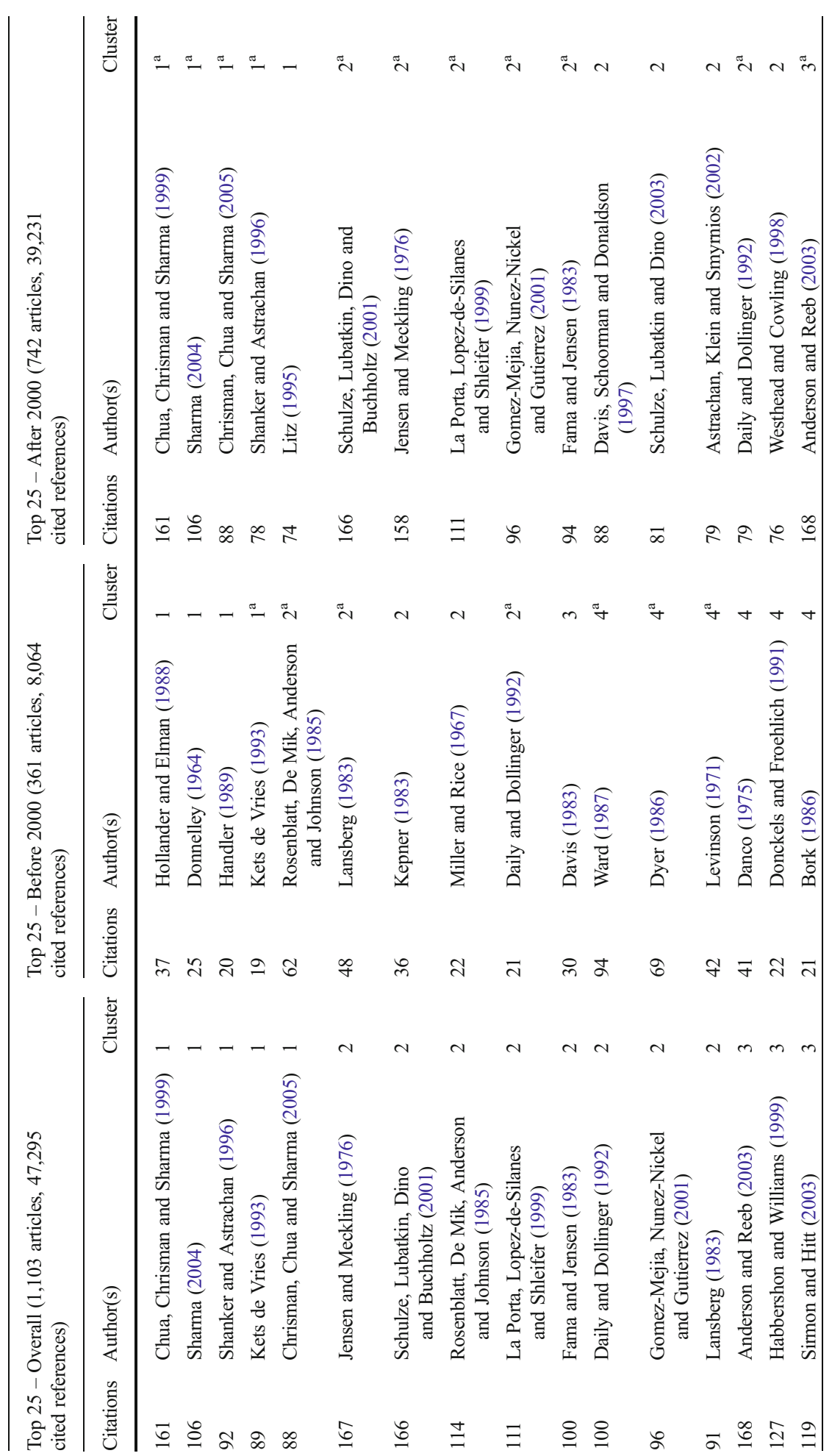




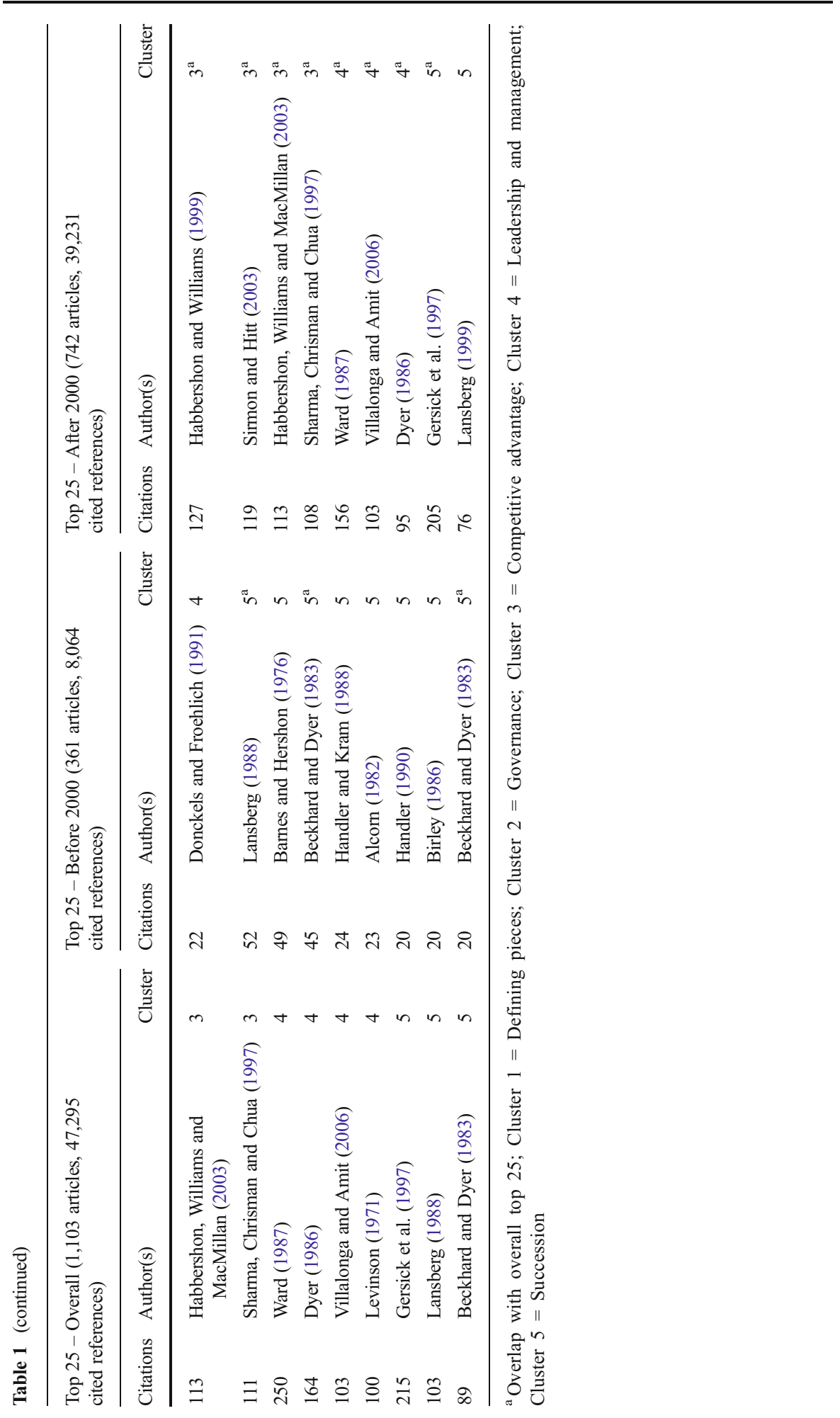


Cowling 1998; Lansberg 1999; Astrachan et al. 2002; Schulze et al. 2003). The degree of overlap with the general top 25 list is not surprising, as the number of publications in the family business field has increased dramatically, with authors building on these insights especially after 2000 .

While defining pieces are cited to the same degree before and after 2000, differences prevail in terms of citation intensity and therefore research focus with regard to the remaining clusters. The results of the analysis show that in early years, succession as well as leadership and management are highly cited and researched subjects that show a large number of influential publications in each topic cluster. In later years, the emphasis lies more on governance issues and the topic of competitive advantage.

\section{Discussion and future directions}

Revisiting and extending upon the studies by Chrisman et al. (2010) and Debicki et al. (2009), our paper offers the first truly comprehensive assessment of family business research across fields. We used the bibliometric techniques of citation and co-citation analysis to map the intellectual structure of family business research as manifested in the overall literature from its beginning and all the way to 2012 .

The development of the field has focused on two different pathways. One has examined the differences between family and non-family businesses (e.g., Chrisman et al. 2009), including but not limited to family involvement, non-economic goals, vision, and family culture. The other centers on highlighting unique family businessspecific aspects and confines research to a family business sample (e.g., Eddleston et al. 2013). The current state of the literature offers ample opportunity for additional research in both realms.

Specifically, we identified the top 25 publications in the most-cited list, and split the list further into publications before and after 2000. These contributions still define the way we think about family business today. To mention just a few, the work by Chua et al. (1999) provides a behavioral definition of family business; Habbershon and Williams (1999) introduce the term "familiness"; and Beckhard and Dyer (1983) discuss the systematic structure of transition. We encourage researchers and new scholars to revisit these seminal contributions found within our top $25 \operatorname{list}(\mathrm{s})$ to gain a solid understanding of the foundations of our field and to address the many remaining future research avenues highlighted in the identified papers.

We further clustered the identified literature into five topical areas in an attempt to extract the key conclusions and areas where further development is needed, thus providing a "big picture" perspective of family business research. In Cluster 1, component and behavioral defining approaches are fully discussed. Cluster 2, the governance cluster, has given back the most to non-family business literature. Cluster 3, the competitive advantage cluster, highlights the challenges in our operationalization of family firms' specific measures. Cluster 4 was labeled the leadership and management cluster. In more micro focused areas, many questions remain unanswered here, and the absence of the application of leadership theories is striking. Cluster 5, the succession cluster, is losing the research prominence that it once had (Dyer and Sánchez 1998), even though many opportunities still remain in this realm. For example, in China, most family businesses have only a 30-year history, and the succession wave that is still to 
come may provide both a fertile data source as well as an opportunity for research to provide guidance in actual succession processes.

Our analysis identifies important contributions and highlights differences in citation patterns before and after 2000. However, the field is only beginning to develop a theory of the family business (e.g., Chrisman et al. 2003). Many additional avenues for future research have been suggested, such as governance and agency and non-economic goals (e.g., Chrisman et al. 2010; Wright and Kellermanns 2011; Gedajlovic et al. 2012). Two significant areas for future development should also be noted: Our suggestions are mainly based on the analysis of the 25 most frequently cited contributions after 2000 . The examination of highly important contributions in recent years has allowed the identification of emerging topics that are now receiving increasing attention by scholars. As a result of this, the advancement of SEW research and the need for taking a micro perspective into account have been identified as offering vast potential for future research. We will discuss both in more detail below.

\section{Socio-emotional wealth}

The 2001 paper by Gómez-Mejía et al., ranked among the most-cited papers after 2000, started the further development of SEW research in family businesses (e.g., GómezMejía et al. 2007; Gómez-Mejía et al. 2010; Cennamo et al. 2012; Zellweger et al. 2012). While these recent works do not yet appear on the list of the most influential articles, this research stream has received strong attention, with many papers already published or in the review process.

Many issues however remain unexplored. Although most SEW research has used this construct as an explanation for behavior, only one study to date has indirectly assessed SEW (Zellweger et al. 2012), while others assume SEW to be present and use it to explain behavior without directly measuring it. Accordingly, the need to develop direct measures of SEW is clear, with first attempts made by Berrone et al. (2012) and Debicki (2012). In addition, SEW (as wealth implies) has been associated with positive outcomes and positive behavior. It's easy enough to imagine that an overbearing influence of the family and a quest for non-economic achievements could easily negatively affect individual family members (Kellermanns et al. 2012).

Future research will therefore need to explore a variety of avenues in relation to SEW (also see Berrone et al. 2012). First, we need a better understanding of how reference points are developed, which factors influence reference point formation (see also Kahneman and Tversky 1979; Baucells et al. 2011), as well as the dimensions underlying SEW and how they interact (Kellermanns et al. 2012). Finally, we need to link the direct measurement of SEW to both macro- and micro-level outcome variables.

\section{A micro perspective}

Family business research, which is associated with entrepreneurship research, is predominantly conducted in the tradition of strategic management research (Zahra and Sharma 2004; Chrisman et al. 2005). Because topics such as SEW have emotional content, it seems warranted that more research should be conducted with a predominantly micro (organizational behavior) orientation. We have long known that negative emotions such as relationship conflict (Levinson 1971) can harm family businesses. 
But how emotions influence the family business over time is virtually unknown (for exceptions, see Morris et al. 2010; Stanley 2010).

Other micro-dependent variables should be further investigated. For example, classic topics such as organizational commitment (e.g., Sharma and Irving 2005; Memili et al. 2013), satisfaction (e.g., Sharma et al. 2001; Sharma et al. 2003), team processes (e.g., Kellermanns and Eddleston 2004), justice (e.g., Barnett and Kellermanns 2006), and culture (e.g., Dyer 1988), need to be fully explored. Areas such as motivation of both family and non-family employees, mentoring of family and non-family employees, and leadership have received only minor attention in the family business literature. Nonfamily business member-related research is in fact sparse (e.g., Barnett and Kellermanns 2006; Madison and Kellermanns 2013) and is urgently needed. After all, the majority of family business employees tend to be non-family members.

\section{Limitations}

There are limitations to the objectivity of our analysis' results. First, based on a profound sample, we tried to elaborate a representative overview of the evolution and the current state of family business research. Although the most comprehensive effort of this nature to date, our literature search still may not have captured all family business-related papers. Second, the subjectivity of the researcher regarding the choice of data and the interpretation of its results represents another limitation. Third, the application of bibliometric methods induces constraints. Because publications need time to show a significant impact, we can only show trends; we cannot predict what the future most influential papers of the field will be. Fourth, limiting the discussion to the top 25 most frequently cited references in our overall dataset restricts our results. With this in mind however, the aim was in fact to discern the intellectual structure as well as the development of family business research based on the most influential publications. Finally, we acknowledge that the clusters' collocation is subjective. Other researchers might have clustered the top 25 publications differently.

\section{References}

Aguilera, R. V., \& Jackson, G. (2003). The cross-national diversity of corporate governance: dimensions and determinants. Academy of Management Review, 28(3), 447-465.

Alcorn, P. B. (1982). Success and survival in the family owned business. New York: McGraw-Hill.

Aldrich, H., \& Cliff, J. (2003). The pervasive effects of family on entrepreneurship: toward a family embeddedness perspective. Journal of Business Venturing, 18(5), 573-597.

Anderson, R., \& Reeb, D. (2003). Founding-family ownership and firm performance: evidence from the S\&P 500. Journal of Finance, 58(3), 1301-1328.

Astrachan, J. H., Klein, S. B., \& Smyrnios, K. X. (2002). The F-PEC scale of family influence: a proposal for solving the family business definition problem. Family Business Review, 15(1), 45-58.

Barnes, L. B., \& Hershon, S. A. (1976). Transferring power in the family business. Harvard Business Review, 54(4), 105-114.

Barnett, T., \& Kellermanns, F. W. (2006). Are we family and are we treated as family? Nonfamily employees' perceptions of justice in the family firm. Entrepreneurship: Theory and Practice, 30(6), 837-854.

Baucells, M., Weber, M., \& Welfens, F. (2011). Reference-point formation and updating. Management Science, 57(3), 506-519. 
Beckhard, R., \& Dyer, W. G. (1983). Managing continuity in the family-owned business. Organizational Dynamics, 12(1), 5-12.

Benavides-Velasco, C. A., Quintana-García, C., \& Guzmán-Parra, V. F. (2013). Trends in family business research. Small Business Economics, 40(1), 41-57.

Berrone, P., Cruz, C., \& Gómez-Mejía, L. R. (2012). Socioemotional wealth in family firms: theoretical dimensions, assessment approaches, and agenda for future research. Family Business Review, 25(3), 258-279.

Birley, S. (1986). Succession in the family firm: the inheritor's view. Journal of Small Business Management, 24(3), 36-43.

Bork, D. (1986). Family business, risky business. New York: AMACOM.

Casillas, J. C., \& Acedo, F. J. (2007). Evolution of the intellectual structure of family business literature: a bibliometric study of FBR. Family Business Review, 20(2), 141-162.

Cennamo, C., Berrone, P., Cruz, C., \& Gómez-Mejía, L. R. (2012). Socioemotional wealth and proactive stakeholder engagement: why family-controlled firms care more about their stakeholders. Entrepreneurship: Theory and Practice, 36(6), 1153-1173.

Chrisman, J. J., Chua, J. H., \& Steier, L. P. (2003). An introduction to theories of family business. Journal of Business Venturing, 18(4), 441-448.

Chrisman, J. J., Chua, J. H., \& Litz, R. A. (2004). Comparing the agency costs of family and non-family firms: conceptual issues and exploratory evidence. Entrepeneurship Theory and Practice, 28(4), 335-354.

Chrisman, J. J., Chua, J. H., \& Sharma, P. (2005). Trends and directions in the development of a strategic management theory of the family firm. Entrepreneurship: Theory and Practice, 29(5), 555-575.

Chrisman, J. J., Chua, J. H., \& Kellermanns, F. W. (2009). Priorities, resource stocks, and performance in family and nonfamily. Entrepreneurship: Theory and Practice, 33(3), 739-760.

Chrisman, J. J., Kellermanns, F. W., Chan, K. C., \& Liano, K. (2010). Intellectual foundations of current research in family business: an identification and review of 25 influential articles. Family Business Review, 23(1), 9-26.

Chua, J. H., Chrisman, J. J., \& Sharma, P. (1999). Defining family business by behavior. Entrepreneurship: Theory and Practice, 24, 19-39.

Daily, C. M., \& Dollinger, M. J. (1992). An empirical examination of ownership structure in family and professionally managed firms. Family Business Review, 5(2), 117-136.

Danco, L. A. (1975). Beyond survival: A business owner's guide for success. Cleveland: The University Press.

Davis, P. S. (1983). Realizing the potential of the family business. Organisational Dynamics, 12(1), 47-56.

Davis, J. H., Schoorman, F. D., \& Donaldson, L. (1997). Toward a stewardship theory of management. Academy of Management Review, 22(1), 20-47.

De Massis, A., Chua, J. H., \& Chrisman, J. J. (2008). Factors preventing intra-family succession. Family Business Review, 21(2), 183-199.

Debicki, B. J. (2012). Socioemotional Wealth and Family Firm Internationalization: The moderating effect of environmental munificence (Vol. Doctoral Dissertation). Mississippi State: Mississippi State University.

Debicki, B. J., Matherne, C. F., Kellermanns, F. W., \& Chrisman, J. J. (2009). An overview of the who, the where, the what and the why. Family Business Review, 22(2), 151-166.

Donckels, R., \& Fröhlich, E. (1991). Are family businesses really different? European experiences from STRATOS. Family Business Review, 4(2), 149-160.

Donnelley, R. G. (1964). The family business. Harvard Business Review, 42(4), 93-105.

Dyer, W. G. (1986). Cultural change in family firms: Anticipating and managing business and family transitions. San Francisco: Jossey-Bass.

Dyer, W. G. (1988). Culture and continuity in family firms. Family Business Review, 1(1), 37-50.

Dyer, W. G. (2003). The family: the missing variable in organizational research. Entrepreneurship: Theory and Practice, 27(4), 401-416.

Dyer, W. G., \& Sánchez, M. (1998). Current state of family business theory and practice as reflected in family business review 1988-1997. Family Business Review, 11(4), 287-295.

Eddleston, K.A., Walsh, H.C., Kellermanns, F.W., Floyd, S.W., E.M., I., Crittenden, V.L., et al. (2013). Planning for growth: life stage differences in family firms. Entrepreneurship Theory and Practice, 37(5), 1177-1202.

Fama, E. F., \& Jensen, M. C. (1983). Separation of ownership and control. Journal of Law and Economics, 26(2), 301-325.

Gedajlovic, E., Carney, M., Chrisman, J. J., \& Kellermanns, F. W. (2012). The adolescence of family firm research: taking stock and planning for the future. Journal of Management, 38(4), 1010-1037.

Gersick, K., Davis, J., Hampton, M., \& Lansberg, I. (1997). Generation to generation: Life cycles of the family business. Boston: Harvard Business School Press.

Gomez-Mejia, L. R., Nunez-Nickel, M., \& Gutierrez, I. (2001). The role of family ties in agency contracts. Academy of Management Journal, 44(1), 81-95. 
Gómez-Mejía, L. R., Haynes, K. T., Núñez-Nickel, M., Jacobson, K. J. L., \& Moyano-Fuentes, H. (2007). Socioemotional wealth and business risk in family-controlled firms: evidence from Spanish Olive oil mills. Administrative Science Quarterly, 52(1), 106-137.

Gómez-Mejía, L. R., Makri, M., \& Larraza-Kintana, M. (2010). Diversification decisions in family-controlled firms. Journal of Management Studies, 47(2), 223-252.

Gundolf, K., \& Filser, M. (2013). Management research and religion: a citation analysis. Journal of Business Ethics, 112(1), 177-185.

Habbershon, T. G., \& Williams, M. L. (1999). A resource-based framework for assessing the strategic advantages of family firms. Family Business Review, 12(1), 1-25.

Habbershon, T. G., Williams, M., \& MacMillan, I. (2003). A unified systems perspective of family firm performance. Journal of Business Venturing, 18(4), 451-465.

Handler, W. C. (1989). Methodological issues and considerations in studying family businesses. Family Business Review, 2(3), 257-276.

Handler, W. C. (1990). Succession in family firms: a mutual role adjustment between entrepreneur and next generation family members. Entrepeneurship Theory and Practice, 15(1), 37-51.

Handler, W. C., \& Kram, K. E. (1988). Succession in family firms: the problem of resistance. Family Business Review, 1(4), 361-381.

Hollander, B. S., \& Elman, N. S. (1988). Family-owned businesses: an emerging field of inquiry. Family Business Review, 1(2), 145-164.

Jensen, M., \& Meckling, W. (1976). Theory of the firm: managerial behavior. Agency costs and ownership structure. Journal of Financial Economics, 3(4), 305-360.

Kahneman, D., \& Tversky, A. (1979). Prospect theory: an analysis of decision under risk. Econometrica, 47(2), 263-291.

Kellermanns, F. W., \& Eddleston, K. A. (2004). Feuding families: when conflict does a family firm good. Entrepreneurship: Theory and Practice, 28(3), 209-228.

Kellermanns, F. W., \& Eddleston, K. A. (2007). A family perspective on when conflict benefits family firm performance. Journal of Business Research, 60(10), 1048-1057.

Kellermanns, F. W., Eddleston, K. A., \& Zellweger, T. M. (2012). Extending the socioemotional wealth perspective: the dark side. Entrepreneurship: Theory and Practice, 36(6), 1175-1182.

Kepner, E. (1983). The family and the firm: a coevolutionary perspective. Organisational Dynamics, 12(1), 57-70.

Kets de Vries, M. F. R. (1993). The dynamics of family controlled firms: the good and the bad news. Organizational Dynamics, 21(3), 59-71.

Kraus, S., Filser, M., Götzen, T., \& Harms, R. (2011a). Familienunternehmen: Zum State-of-the-Art der betriebswirtschaftlichen Forschung (family businesses: on the State-of-the-Art of business research). Betriebswirtschaftliche Forschung und Praxis, 63(6), 587-605.

Kraus, S., Fink, M., \& Harms, R. (2011b). Family firm research: sketching a research field. International Journal of Entrepreneurship \& Innovation Management, 13(1), 32-47.

Kraus, S., Filser, M., O’Dwyer, M., \& Shaw, E. (2013). Social entrepreneurship: an exploratory citation analysis. Review of Managerial Science, 1-18.

Kuhn, T. S. (1962). The structure of scientific revolutions. Chicago: University of Chicago Press.

La Porta, R., Lopez-de-Silanes, F., \& Shleifer, A. (1999). Corporate ownership around the world. Journal of Finance, 54(2), 471-517.

Lansberg, I. S. (1983). Managing human resources in family firms: the problem of institutional overlap. Organizational Dynamics, 12(1), 39-46.

Lansberg, I. (1988). The Succession Conspiracy: Mapping Resistance to Succession Planning in First Generation Family Firms. Working Paper A 70. Yale: Yale School of Organization and Management.

Lansberg, I. (1999). Succeeding generations: Realizing the dream of families in business. Boston: Harvard Business School Press.

Lansberg, I., \& Astrachan, J. H. (1994). Influence of family relationships on succession planning and training: the importance of mediating factors. Family Business Review, 7(1), 39-59.

Levinson, H. (1971). Conflicts that plague family business. Harvard Business Review, 49(3-4), 91-98.

Litz, R. A. (1995). The family business: toward definitional clarity. Family Business Review, 8(2), 71-81.

Madison, K., \& Kellermanns, F. W. (2013). Is the spiritual bond bound by blood? An exploratory study of spiritual leadership in family firms. Journal of Management, Spirituality and Religion, 10(2), 159-182.

Memili, E., Zellweger, T. M., \& Fang, H. C. (2013). The determinants of family owner-managers' affective organiational commitment. Family Relations, 62(3), 443-456.

Miller, E. J., \& Rice, A. K. (1967). Systems of Organization. London: Tavistock.

Miller, D., Breton-Miller, L., \& Lester, R. H. (2011). Family and lone founder ownership and strategic behaviors: social contexts, identity, and institutional logics. Journal of Management Studies, 48(1), 1-25. 
Moed, H. F. (2005). Citation analysis in research evaluation. Dordrecht: Springer.

Morris, M. H., Allen, J. A., Kuratko, D. F., \& Brannon, D. (2010). Experiencing family business creation: differences betwen founders, non-family managers and founders of non-family firms. Entrepreneurship: Theory and Practice, 34(6), 1057-1084.

Prévot, F., Branchet, B., Boissin, J.-P., Castagnos, J.-C., \& Guieu, G. (2010). The Intellectual Structure of the Competence-Based Management Field: A Bibliometric Analysis. In R. Sanchez, A. Heene, \& T. E. Zimmermann (Eds.), Research in competence-based management - a focused issue on identifying, building, and linking competences (Vol. 5, pp. 231-258). Bingley: Emerald Group Publishing Limited.

Rosenblatt, P. C., de Mik, L., Anderson, R. M., \& Johnson, P. A. (1985). The family in business: Understanding and dealing with the challenges entrepreneurial families face. San Francisco: Jossey-Bass.

Schulze, W. S., Lubatkin, M. H., Dino, R. N., \& Buchholtz, A. K. (2001). Agency relationship in family firms: theory and evidence. Organization Science, 12(9), 99-116.

Schulze, W. S., Lubatkin, M. H., \& Dino, R. N. (2003). Toward a theory of agency and altruism in family firms. Journal of Business Venturing, 18(4), 473-490.

Shanker, M. C., \& Astrachan, J. H. (1996). Myths and realities: family businesses' contribution to the US economy: a framework for assessing family business statistics. Family Business Review, 9(2), 107-123.

Sharma, P. (2004). An overview of the field of family business studies: current status and directions for the future. Family Business Review, 17(1), 1-36.

Sharma, P., \& Irving, P. G. (2005). Four bases of family business successor commitment: antecedents and consequences. Entrepreneurship: Theory and Practice, 29(1), 13-33.

Sharma, P., Chrisman, J. J., \& Chua, J. H. (1997). Strategic management of the family business: past research and future challenges. Family Business Review, 10(1), 1-36.

Sharma, P., Chrisman, J. J., Pablo, A. L., \& Chua, J. H. (2001). Determinants of initial satisfaction with the succession process in family firms: a conceptual model. Entrepreneurship: Theory and Practice, 25(3), 17-35.

Sharma, P., Chrisman, J. J., \& Chua, J. H. (2003). Predictors of satisfaction with the succession process in family firms. Journal of Business Venturing, 18(5), 667-687.

Sharma, P., Chrisman, J. J., \& Gersick, K. (2012). Twenty five years of family business review: reflections on the past and perspectives for the future. Family Business Review, 25(1), 5-15.

Sirmon, D., \& Hitt, M. A. (2003). Managing resources: linking unique resources, management and wealth creation in family firms. Entrepreneurship: Theory and Practice, 27(4), 339-359.

Sorenson, R. L. (1999). Conflict management strategies used in successful family businesses. Family Business Review, 12(4), 325-339.

Stanley, L. (2010). Emotions and family business creation: an extension and implications. Entrepreneurship: Theory and Practice, 34(6), 1085-1092.

Stewart, A., \& Hitt, M. A. (2012). Why Can't a family business be more like a nonfamily business?: Modes of professionalization in family firms. Family Business Review, 25(1), 33-57.

Van Essen, M., Carney, M., Gedajlovic, E., \& Heugens, P. (2011). Do U.S. Publicaly-Listed Family Firms Differ? Does it Matter? A Meta-Analysis. In Academy of Management Best Papers Proceedings, San Antonio, Texas.

Villalonga, B., \& Amit, R. (2006). How do family ownership, control and management affect firm value? Journal of Financial Economics, 80(2), 385-417.

Ward, J. (1987). Keeping the family business healthy: how to plan for continuing growth, profitability and family leadership. San Francisco: Jossey-Bass.

Westhead, P., \& Cowling, M. (1998). Family business research: the need for a methodological rethink. Entrepreneurship: Theory and Practice, 23(1), 31-57.

Wright, M., \& Kellermanns, F. W. (2011). What can family firm research learn from management and entrepreneurship? Journal of Family Business Strategy, 2(4), 187-198.

Yu, A., Lumpkin, G. T., Brigham, K. H., \& Sorenson, R. L. (2012). The landscape of family business outcomes: a summary and numerical taxonomy of dependent variables. Family Business Review, 25(1), 33-57.

Yue, W., \& Wilson, C. S. (2004). Measuring the citation impact of research journals in clinical neurology: a structural equation modelling analysis. Scientometrics, 90(3), 317-332.

Zahra, S. A., \& Sharma, P. (2004). Family business research: a strategic reflection. Family Business Review, 17(4), 331-346.

Zellweger, T. M., Eddleston, K. A., \& Kellermanns, F. W. (2010). Exploring the concept of familiness: introducing family firm identity. Journal of Family Business Strategy, 1(1), 54-63.

Zellweger, T. M., Kellermanns, F. W., Chrisman, J. J., \& Chua, J. H. (2012). Family control and family firm valuation by family CEOs: the importance of intentions for transgenerational control. Organization Science, 23(3), 851-868. 